\title{
ASSESSMENT OF THE IMPACT OF LAND USE CHANGES ON NET PRIMARY PRODUCTIVITY USING HUMAN APPROPRIATION OF NET PRIMARY PRODUCTIVITY IN ANJI, CHINA
}

\author{
HuANG, Y. ${ }^{1}-$ CHEN, S. L. ${ }^{2 *}-$ JiAnG, H. ${ }^{3}-$ CHEN, W. J. ${ }^{4}-$ Mo, X. H. ${ }^{5}$ \\ ${ }^{1}$ School of Cyber Security, Jinling Institute of Technology, No. 99 Hongjin Road, Nanjing \\ 211169, Jiangsu, China
}

${ }^{2}$ College of Economics and Management, Nanjing Forestry University, No. 159 Longpan Road, Nanjing 210037, Jiangsu, China

${ }^{3}$ International Institute for Earth System Science, Nanjing University, No. 163 Xianlin Road, Nanjing 210023, Jiangsu, China

${ }^{4}$ School of Software Engineering, Jinling Institute of Technology, No. 99 Hongjin Road, Nanjing 211169, Jiangsu, China

${ }^{5}$ School of Computer Engineering, Jinling Institute of Technology, No. 99 Hongjin Road, Nanjing, 211169, Jiangsu China

*Corresponding author

e-mail: slchen@njfu.edu.cn

(Received 6 Jun 2021; accepted $3^{\text {rd }}$ Sep 2021)

\begin{abstract}
The land use changes (LUC) have altered the vegetation net primary productivity (NPP). Human appropriation of net primary productivity resulting from LUC (HANPP ${ }_{\text {luc }}$ ) can be used to quantify the consequence of LUC on vegetation NPP. HANPP luc is defined as the difference between the potential and actual NPP availability in ecosystems. Based on the Thornthwaite Memorial model, CASA model, and multiple linear regression, this paper estimated the potential and actual NPP, explored the temporal and spatial changes of HANPP $P_{\text {luc }}$, and analyzed the impact of LUC on vegetation NPP in Anji, China. There was a significant increasing trend in annual HANPP luc from 1984 to 2014. The total mean value of $\mathrm{HANPP}_{\text {luc }}$ was $155 \mathrm{Gg} \mathrm{C}_{\text {year }}{ }^{-1}$, while $\mathrm{HANPP}_{\text {luc }}$ per unit was $82 \pm 54 \mathrm{~g} \mathrm{C} \mathrm{m}^{-2}$ year $^{-1}$. The growth of Moso bamboo (Phyllostachys pubescens) forests area caused an increase of $33.5 \mathrm{Gg} \mathrm{C}^{-1} \mathrm{ear}^{-1}$ in NPP. However, the urbanization was the main reason for the decrease of NPP, which resulted in a decrease of $97.9 \mathrm{Gg} \mathrm{C}$ year $^{-1}$ in NPP. This study quantified the impact of LUC on vegetation NPP, and provided key data for urban landscape planning, Moso bamboo management, and regional ecological carbon cycle models.

Keywords: potential NPP, CASA model, Thornthwaite Memorial model, Moso bamboo forests,
\end{abstract} urbanization

\section{Introduction}

The Northern Hemisphere atmospheric $\mathrm{CO}_{2}$ concentration has been successively rising at an increasing rate, mainly due to the continued burning of fossil fuels and land use changes (LUC) (IPCC, 2013). By fixing atmospheric $\mathrm{CO}_{2}$, the forest ecosystems and cropland ecosystems mitigate the rise in $\mathrm{CO}_{2}$, and play important roles in the global carbon cycle. The economy in the subtropical region of China has developed rapidly since 1978 , and the economic achievement of China is mainly belonged to the subtropical region (Shi et al., 2020). The rapid economic development had accelerated the process of urbanization, and the area of urban land had increased significantly, which led to the 
decrease in the area of forests and croplands. This is verified by the data on the subtropical region of China, where the area of urban land had increased by $4.9 \%$ of the total area, while the area of forests and croplands had decreased about $15.1 \%$ of the total area during the period 1980-2018. The urbanization has decreased the carbon sequestration ability of the forests and croplands (Chen et al., 2020; Mahbub et al., 2019). Thus, some obvious questions arise: how to monitor and evaluate the carbon fixation ability of the ecosystems, and how to quantify the impact of urbanization on carbon sequestration.

Moso bamboo (Phyllostachys pubescens) forests are common in the subtropical region of China, covering approximately 3.9 million ha of area, and account for $74 \%$ of the Chinese bamboo forests area and 80\% of the world's bamboo forests area (Song et al., 2016). Over the last 30 years, the area of Moso bamboo forests had increased significantly, and the rate of increase was approximately 3\% (Chen et al., 2018; Song et al., 2013). The Moso bamboo growing pattern is greatly different from other forest types and accumulate large amounts of carbon (Cao et al., 2019). How to evaluate the carbon sequestration ability of the Moso bamboo forests, and analyze the impact of the growth of bamboo forests area on carbon sequestration are problems faced by ecologists.

Net primary productivity (NPP), which is equal to the difference between the amount of carbon absorbed by plant photosynthesis and the carbon released by plant respiration, can reflect the carbon fixation ability of plants (Garbulsky and Paruelo, 2004). Therefore, quantifying the consequence of LUC on vegetation NPP will guide urbanization, control the decrease of ecosystem NPP, and mitigate the climate warming trends (Foley et al., 2005). Human appropriation of net primary productivity resulting from LUC (HANPP luc $_{\text {) }}$ can be used to quantify the consequence of LUC on vegetation NPP, and has been widely used worldwide (Haberl et al., 2014; Huang et al., 2020; Weinzettel et al., 2019). HANPP $_{\text {luc }}$ is the loss of potential NPP due to LUC, and is defined as the difference between potential and actual NPP availability in ecosystems. Potential NPP ( $\left.\mathrm{NPP}_{\mathrm{pot}}\right)$ is the NPP of native ecosystems that would most likely exist in the absence of human activities, while actual NPP (NPP act) is the NPP of current ecosystems. As a percentage of $\mathrm{NPP}_{\text {pot }}$, the global HANPP luc varied between 4\% and 56\% during the period 1990-2015 (Haberl et al., 2014, 2007; Plutzar et al., 2016; Pritchard et al., 2018; Saikku et al., 2015). In China, HANPP ${ }_{\text {luc }}$ varied between $6 \%$ and $26 \%$ of $\mathrm{NPP}_{\text {pot }}$ during the period 2000-2015 (Chen et al., 2015; Huang et al., 2020; Lin et al., 2016). How to simulate NPP act and $\mathrm{NPP}_{\text {pot }}$ are key problems for HANPP luc $_{\text {estimation. }}$

The Carnegie-Ames-Stanford approach (CASA) model is a widely used method for $\mathrm{NPP}_{\text {act }}$ estimation in China, and the simulated NPP act was consistent with the observed NPP (Chen et al., 2017; Xu and Wang, 2016; Zhang et al., 2016). At present, empirical models that use correlations between climate data and measured NPP at individual sites have been widely used for NPP pot estimation (Lin et al., 2016). Based on Liebig's Law of Minimum, the Miami model uses temperature and precipitation to estimate $\mathrm{NPP}_{\text {pot }}$ (Gang et al., 2014; Zhang et al., 2015). $\mathrm{NPP}_{\text {pot }}$ is not only related to temperature and precipitation, but also to other environmental factors. Actual evapotranspiration is used by the Thornthwaite Memorial model to estimate NPP pot (Liu et al., 2019; Yin et al., 2020). The Chikugo model is the function of precipitation and net surface radiation (Chen et al., 2015).

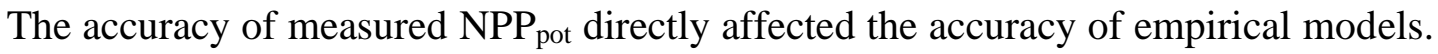
The core zone in a nature reserve is designed to strictly protect ecosystems, and minimize disturbance by human activities (Geneletti and Duren, 2008). The ecosystem 
in the core zone is considered to be a natural ecosystem that is undisturbed by humans (Zhang et al., 2017b). Therefore, the $\mathrm{NPP}_{\text {act }}$ in the core zone would be considered to be

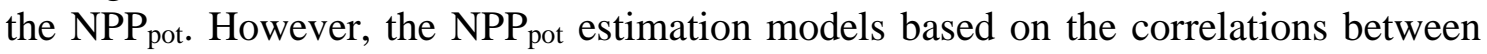
$\mathrm{NPP}_{\mathrm{pot}}$ in the core zone and climate data has not been reported.

Given the above scientific challenges, this study used the CASA model to simulate the $\mathrm{NPP}_{\text {act. }}$ Based on the core zone in the nature reserve, the NPP pot estimation models for the different forest types were established using multiple linear regression. Anji and TianMu Mountain Nature Reserve, located in eastern subtropical China (see Fig. 1a), were selected as test region. The forest types in Anji and the core zone in TianMu Mountain Nature Reserve are similar, and these are Moso bamboo forests (MBF), subtropical broadleaf forests (SBF), and subtropical needle leaf forests (SNLF). Based on the core zone in TianMu Mountain Nature Reserve, the NPP pot estimation models for the three forest types were established using the correlations between the measured $\mathrm{NPP}_{\text {pot }}$ and temperature, precipitation, and solar radiation. The $\mathrm{NPP}_{\text {pot }}$ in the croplands was estimated by the Thornthwaite Memorial model. The objectives of this study were to (1) estimate the $\mathrm{NPP}_{\text {act }}$ and $\mathrm{NPP}_{\text {pot }}$ in Anji, (2) explore the temporal and spatial

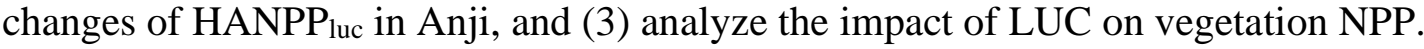

\section{Materials and methods}

\section{Study area}

Anji and the core zone in TianMu Mountain Nature Reserve are located in northwestern Zhejiang Province, China (see Fig. 1b). The area of the core zone in TianMu Mountain Nature Reserve and Anji are about 598 and 188601 ha. The forest types in Anji and the core zone in TianMu Mountain Nature Reserve are the MBF, SBF, and SNLF (see Fig. $1 c$ and $d$ ). The SBF consists of the following six different tree species: Cyclobalanopsis glauca, Castanopsis sclerophylla, Castanopsis sclerophylla, Castanopsis eyrei, Schima superba, and Quercus fabri. The five different tree species in the SNLF are Pinus massoniana, Cryptomeria fortune, Pseudolarix amabilis, Pinus taiwanensis and Cunninghamia lanceolata.

The Moso bamboo growing pattern is greatly different from other forest types. It can reach maximum height $(10-20 \mathrm{~m})$ in 2-4 months, and accumulate large amounts of carbon (Cao et al., 2019). The Moso bamboo is widely distributed in Anji, and the area of it increased significantly during the period 1984-2014. The croplands also exists in Anji, however, the area of the croplands, SBF, and SNLF has been decreased at a rapid rate due to the urbanization and increase of MBF.

\section{Design of HANPPluc estimation procedure}

$\mathrm{HANPP}_{\text {luc }}$ is defined as the difference between $\mathrm{NPP}_{\text {pot }}$ and $\mathrm{NPP}_{\text {act. }}$ The CASA model was used to calculate $\mathrm{NPP}_{\text {act }}$ in Anji and the core zone in TianMu Mountain Nature Reserve from 1984 to 2014. In order to estimate $\mathrm{NPP}_{\text {pot }}$, we assumed that: (1) Because no human activity is permitted in the core zone in a nature reserve (Hull et al., 2011), for the MBF, SBF and SNLF, the NPPact in the core zone in TianMu Mountain Nature Reserve would be considered to be $\mathrm{NPP}_{\text {pot }}$; (2) According to Tobler's first law (TFL) of

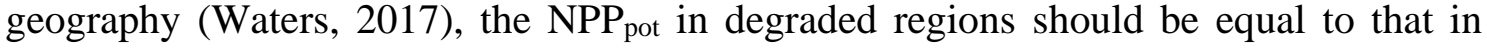
non-degraded regions when the degraded and non-degraded regions have similar natural conditions (Lin et al., 2016). The forest types in Anji and the core zone in TianMu 


$$
-4334 \text { - }
$$

Mountain Nature Reserve are similar. Therefore, the $\mathrm{NPP}_{\text {pot }}$ in the MBF, SBF and SNLF in Anji would be considered to be equal to that in the core zone in TianMu Mountain Nature Reserve.
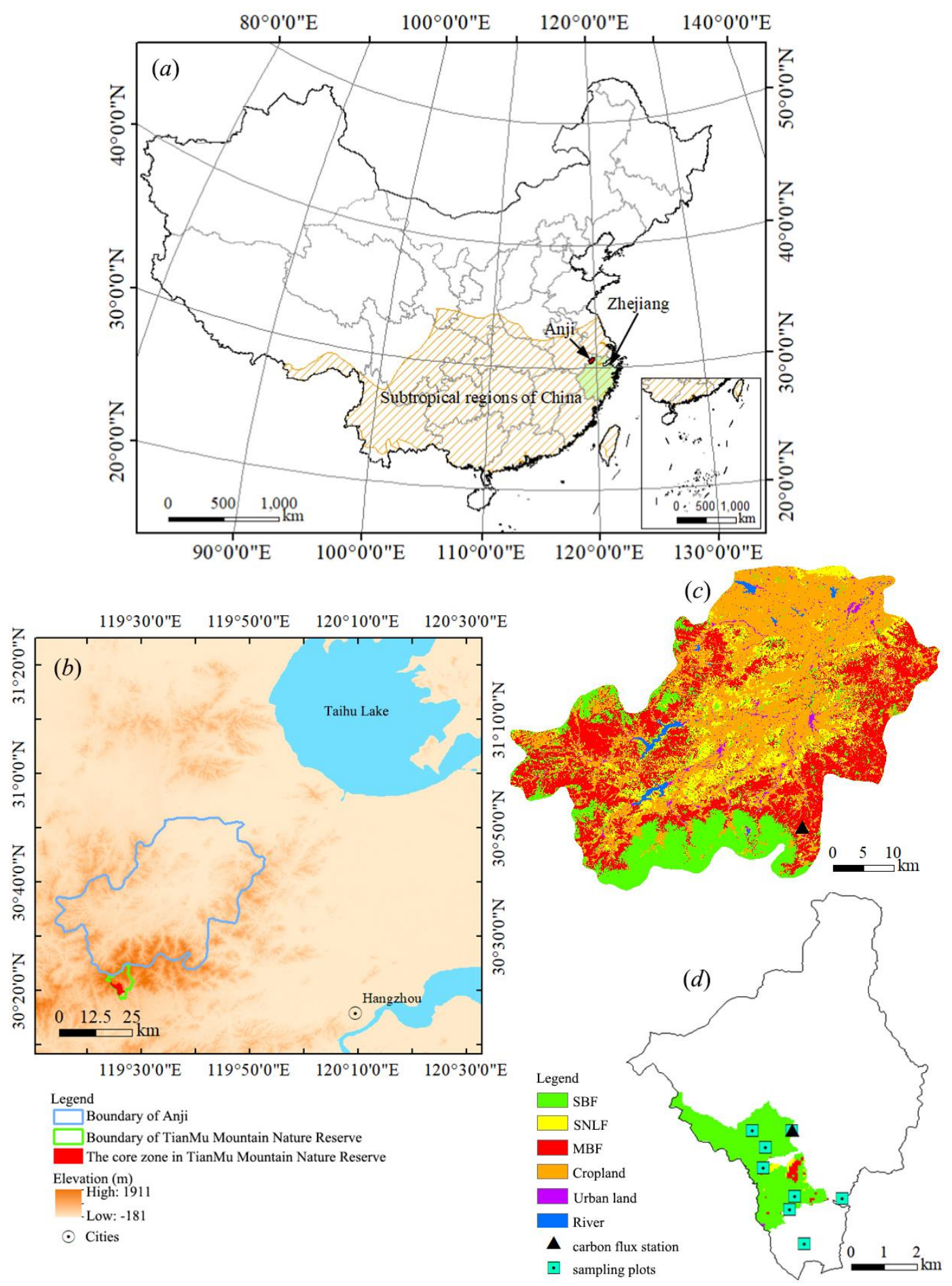

Figure 1. Location of (a) subtropical region of China and (b) Anji and the core zone in TianMu Mountain Nature Reserve, and the land cover maps in (c) Anji and (d) the core zone in TianMu Mountain Nature Reserve. The cyan square points are the plots of in-situ NPP observation, and the black triangle points are the carbon flux stations using the eddy covariance observation systems to measure NPP 
Figure 2 shows the process of the HANPPluc estimation. Firstly, based on the meteorological data, NDVI, and land cover maps, the CASA model was used to estimate the $\mathrm{NPP}_{\text {act }}$ in Anji and the core zone in TianMu Mountain Nature Reserve from 1984 to 2014. Secondly, based on the CASA-simulated NPP act, meteorological data, and land cover maps in the core zone in TianMu Mountain Nature Reserve, the NPP pot estimation models for the SBF, SNLF, and MBF were established using multiple linear regression. Thirdly, according to assumption 2, based on the meteorological data and land cover map in 1984, the NPP pot in the SBF, SNLF, and MBF in Anji was simulated using the $\mathrm{NPP}_{\text {pot }}$ estimation models for the three forest types. Fourthly, based on the meteorological data and land cover map in 1984, the Thornthwaite Memorial model was

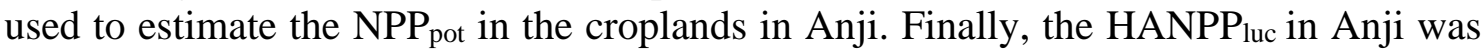
calculated as the difference between $\mathrm{NPP}_{\text {pot }}$ and $\mathrm{NPP}_{\text {act. }}$.

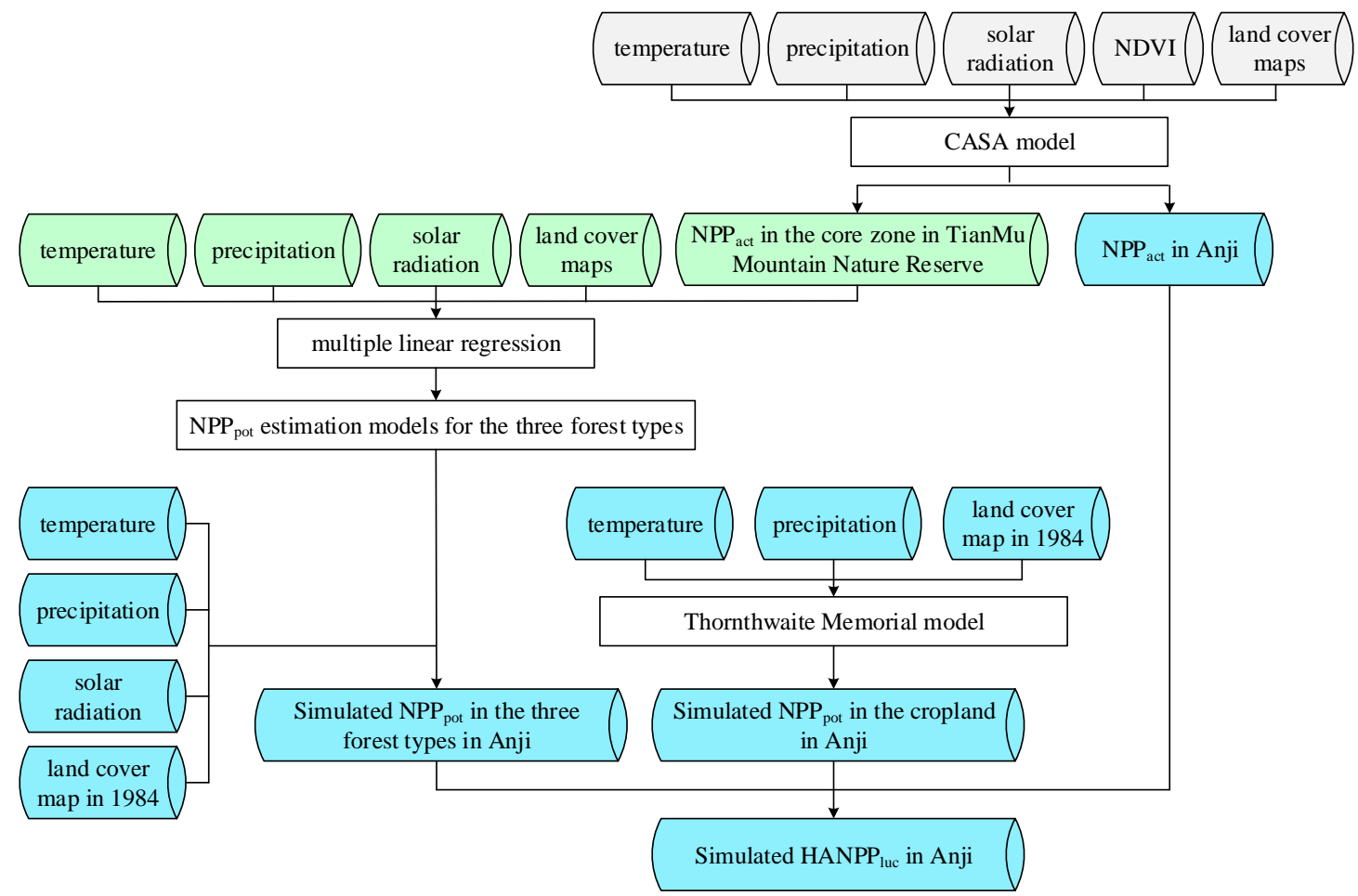

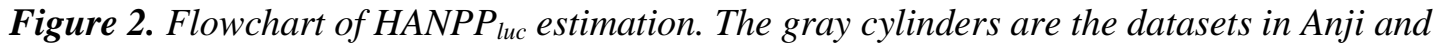
the core zone in TianMu Mountain Nature Reserve, the green cylinders are the datasets in the core zone in TianMu Mountain Nature Reserve, and the blue cylinders are the datasets in Anji

\section{Input data}

The datasets we used for $\mathrm{HANPP}_{\text {luc }}$ estimation are the meteorological datasets, NDVI, and land cover maps. The meteorological datasets, including monthly temperature, monthly precipitation, and monthly solar radiation, were provided by China Meteorological Administration (http://data.cma.cn/). The meteorological datasets are quality controlled, and the percentage of correct data is approaching to $100 \%$. The meteorological datasets were also resampled to match the spatial resolution of HANPP $_{\text {luc }}$ using ordinary kriging method. The NDVI provided by AVHRR Global Inventory Modeling and Mapping Studies (GIMMS) group was used for NPP pot estimation. The NDVI3g dataset was downloaded from NASA Ames Ecological 
Forecasting Lab (https://ecocast.arc.nasa.gov/data/pub/gimms/3g.v1/), and then was resampled to match the spatial resolution of HANPP luc using ordinary kriging method. The land cover maps in Anji were derived from Landsat MSS and OLI scenes using the supervised Maximum-Likelihood classification (Chen et al., 2020).

\section{Field work}

In Tianmu Mountain Nature Reserve, eight sampling plots were selected to validate the NPP of the actual vegetation (see the cyan square points in Fig. 1d), and the size of each plot is $20 \mathrm{~m} \times 20 \mathrm{~m}$. There were four sampling plots in the SBF, three sampling plots in the SNLF, and one sampling plot in the MBF. At each sampling plots, the mean heights, breast diameters and crown diameters of stand-grown trees were derived from the field investigations which carried out during the period 2005-2010.

In the SBF in Tianmu Mountain Nature Reserve, there was one carbon flux observation station which using the eddy covariance observation systems to measure NPP (Chen et al., 2017). The carbon flux observation station was established in 2012, and the measured NPP has been obtained since 2013. In Anji, there was also one carbon flux observation station in the MBF (see Fig. 1c). The carbon flux observation station was established in 2010, and the measured NPP has been obtained since 2011. Details can be found in Chen et al. (2020).

\section{HANPPluc estimation}

HANPP $_{\text {luc }}$ is the loss of the potential NPP due to LUC $\left(\mathrm{g} \mathrm{C} \mathrm{m}^{-2}\right.$ year $\left.^{-1}\right)$, and can be calculated as:

$$
\mathrm{HANPP}_{\text {luc }}=\mathrm{NPP}_{\text {pot }}-\mathrm{NPP}_{\text {act }}
$$

where NPP $\mathrm{Not}_{\text {is }}$ the NPP of the potential natural vegetation that would most likely exist in the absence of human-led land use $\left(\mathrm{g} \mathrm{C} \mathrm{m}^{-2}\right.$ year $\left.^{-1}\right)$, and $\mathrm{NPP}_{\text {act }}$ is the NPP of the actual vegetation $\left(\mathrm{g} \mathrm{C} \mathrm{m}^{-2}\right.$ year $\left.^{-1}\right)$.

\section{NPPact estimation}

The CASA model was used to estimate the $\mathrm{NPP}_{\text {act. }}$ The monthly value of $\mathrm{NPP}_{\text {act }}$ can be calculated as (Field et al., 1995; Potter et al., 1993):

$$
\mathrm{NPP}_{\text {act }}=0.5 \times S \times \mathrm{FPAR} \times T_{\varepsilon} \times W_{\varepsilon} \times \mathrm{LUE}_{\max }
$$

where $S$ is the total solar radiation reaching the earth's surface (MJ month ${ }^{-1}$ ). FPAR is the fraction of photosynthetically active radiation and was calculated following the procedure of Zhu et al. (2006). $T_{g}$ is the temperature stress indicator, $W_{g}$ is the water stress indicator. The equations of $T_{\varepsilon}$ and $W_{s}$ can be found in Potter et al. (1993). $\mathrm{LUE}_{\max }$ is the maximum light-use efficiency of the vegetation $\left(\mathrm{g} \mathrm{C} \mathrm{MJ}^{-1}\right)$, and the values

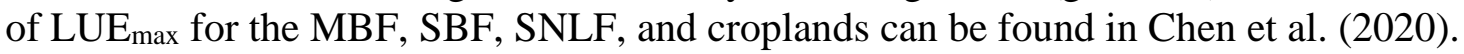

\section{$N P P_{p o t}$ estimation}

The Thornthwaite Memorial model was used for the $\mathrm{NPP}_{\text {pot }}$ estimation in the croplands. The Thornthwaite Memorial model uses the relationship between actual 
evapotranspiration and carbon fixation to estimate $\mathrm{NPP}_{\text {pot }}$ (Lieth, 1975; Liu et al., 2019). The yearly value of $\mathrm{NPP}_{\text {pot }}$ can be calculated as:

$$
\begin{gathered}
\mathrm{NPP}_{\text {pot }}=3000\left[1-\mathrm{e}^{-0.0009695(V-20)}\right] \\
V=\frac{1.05 \text { Pree }}{\sqrt{1+(1.05 \text { Prec } / L)^{2}}}
\end{gathered}
$$$$
L=300+25 T \text { emp }+0.05 T_{e m p}{ }^{3}
$$

where $V$ is the mean annual actual evapotranspiration $(\mathrm{mm})$, Prec is the mean annual precipitation $(\mathrm{mm}), L$ is annual maximum evapotranspiration $(\mathrm{mm})$, and Temp is mean annual temperature $\left({ }^{\circ} \mathrm{C}\right)$.

The NPP ${ }_{\text {pot }}$ was affected by the temperature, precipitation, and solar radiation in Anji and the core zone in TianMu Mountain Nature Reserve (see Table 1). Therefore, the $\mathrm{NPP}_{\text {pot }}$ estimation models for the SBF, SNLF, and MBF were established using multiple linear regression. The multilinear regression equation is

$$
\mathrm{NPP}_{\mathrm{pot}}=a \times T_{a}+b \times P+c \times S+d
$$

where $T_{a}$ is the mean monthly temperature $\left({ }^{\circ} \mathrm{C}\right), P$ is the monthly precipitation $(\mathrm{mm}), S$ is the monthly solar radiation ( $\mathrm{MJ}$ month $^{-1}$ ), $a, b, c$, and $d$ are the regression coefficients.

Table 1. Pearson correlation coefficient $(R)$ between $N P P_{p o t}$ and temperature $\left(T_{a}\right)$, precipitation $(P)$, and solar radiation $(S)$ for each forest type

\begin{tabular}{c|c|c|c}
\hline Forest type & $\boldsymbol{T}_{\boldsymbol{a}}$ & $\boldsymbol{P}$ & $\boldsymbol{S}$ \\
\hline SBF & $0.81^{*}$ & $0.28^{*}$ & $0.82^{*}$ \\
SNLF & $0.79^{*}$ & $0.27^{*}$ & $0.80^{*}$ \\
MBF & $0.82^{*}$ & $0.29^{*}$ & $0.83^{*}$ \\
\hline
\end{tabular}

*At $5 \%$ signification level

\section{Land use transition matrix}

The land use transition matrix was used to detect the transition of different land cover type during the period 1984-2014 (Lü et al., 2020). The area of one land cover type in the year 1984 can be calculated as:

$$
\mathrm{A}_{i+}=\sum_{i=1}^{n} \mathrm{~A}_{i j}
$$

where $\mathrm{A}_{i j}(i \neq j)$ is the area of the land cover type that was converted from type $i$ to type $j$ between 1984 and 2014, $n$ is the number of land cover type, $A_{i i}$ is the area of the land cover type that showed the persistence of type $i$ between 1984 and 2014.

The area of the land cover type that was occupied by type $\mathrm{j}$ in the year 2014 is

$$
\mathrm{A}_{+j}=\sum_{j=1}^{n} \mathrm{~A}_{i j}
$$




\section{Changing trend}

The slope of linear regression equation was used to calculate the HANPP $\mathrm{Huc}_{\text {changing }}$ trend during the period 1984-2014, and can be calculated as:

$$
\text { slope }=\frac{n \times \sum_{i=1}^{m}\left(i \times H_{A N P P}\right)-\sum_{l=1}^{n} i \times \sum_{i=1}^{n} \operatorname{HANPP}_{\operatorname{luci}}}{n \times \sum_{i=1}^{m} i^{2}-\left(\sum_{i=1}^{n} i\right)^{2}}
$$

where $n$ is the number of years $(n=31), \mathrm{HANPP}_{\text {luc }_{j}}$ is the $\mathrm{HANPP}_{\text {luc }}$ in the year $i$. A positive slope value indicates that the $\mathrm{HANPP}_{\text {luc }}$ is in an upward trend, and a negative slope value means that the $\mathrm{HANPP}_{\text {luc }}$ is in a decreasing trend.

\section{Results}

\section{Spatial pattern of LUC}

Figure 3 shows the LUC in Anji during the period 1984-2014. The land use transition matrix was obtained using Equations 7-8 (Table 2). Over the last 31 years, there was about 57.8\% of the total area of Anji where the land cover type were not changed. The area of MBF increased from 30.4\% of the total area of Anji in 1984 to $43.7 \%$ in 2014, while the area of SBF and SNLF decreased about 7317 and 5666 ha. The area of croplands also decreased about 25324 ha due to the urban expansion, and the area of urban land increased from 2.0\% of the total area of Anji in 1984 to $8.5 \%$ in 2014. The area of river increased about 809 ha during the period 1984-2014.
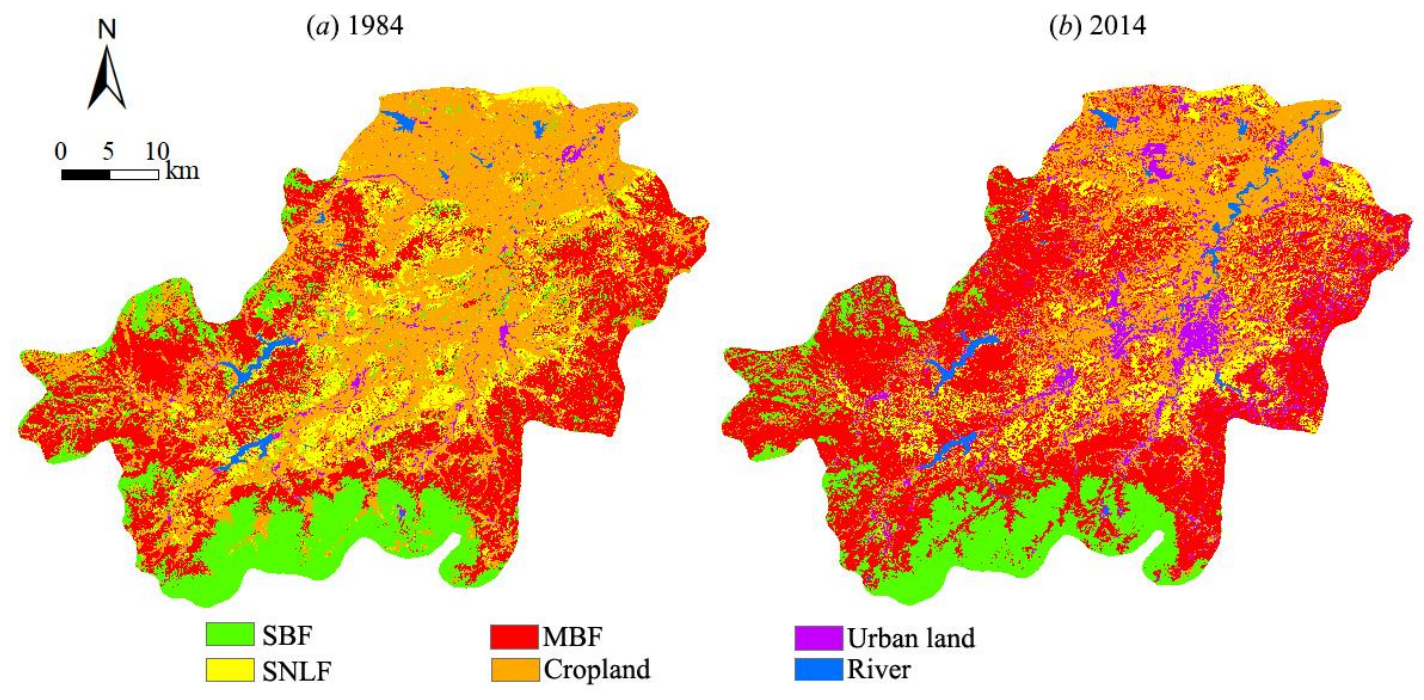

Figure 3. The land cover maps in the year (a) 1984 and (b) 2014

\section{NPP act estimation and validation}

The NPPact in Anji and TianMu Mountain Nature Reserve were simulated by the CASA model (see Eq. 2). The observed $\mathrm{NPP}_{\text {act }}$ at the eight sampling plots in Tianmu Mountain Nature Reserve were used to validate the simulated $\mathrm{NPP}_{\text {act }}$ (see Fig. 4a). The results show that the simulated annual $\mathrm{NPP}_{\text {act }}$ was largely consistent with the observed $\mathrm{NPP}_{\text {act }}\left(R^{2}=0.91, p<0.01\right)$, and the value of RMSE was $73 \mathrm{~g} \mathrm{C} \mathrm{m}^{-2}$ year $^{-1}$. 


$$
\text { - } 4339 \text { - }
$$

Table 2. Land use transition matrix (unit: ha) of Anji during the period 1984-2014

\begin{tabular}{c|c|c|c|c|c|c}
\hline & SBF & SNLF & MBF & Croplands & Urban & River \\
\hline SBF & 18,215 & 667 & 10,335 & 1,330 & 523 & 118 \\
SNLF & 656 & 8,763 & 9,528 & 3,484 & 918 & 23 \\
MBF & 2,472 & 4,592 & 43,211 & 3,949 & 3,192 & 33 \\
Croplands & 2,513 & 3,638 & 19,359 & 35,551 & 9,365 & 838 \\
Urban & 14 & 45 & 214 & 1,505 & 1,852 & 155 \\
River & 2 & 0 & 9 & 121 & 226 & 1,621 \\
\hline
\end{tabular}

(a)

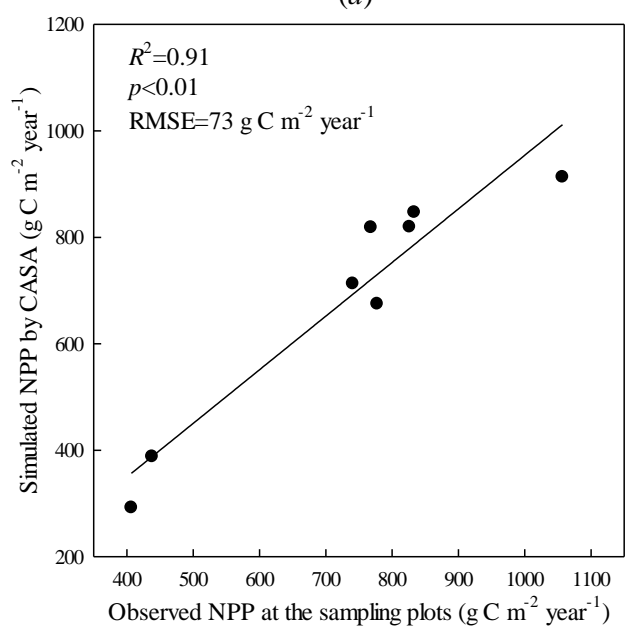

(c)

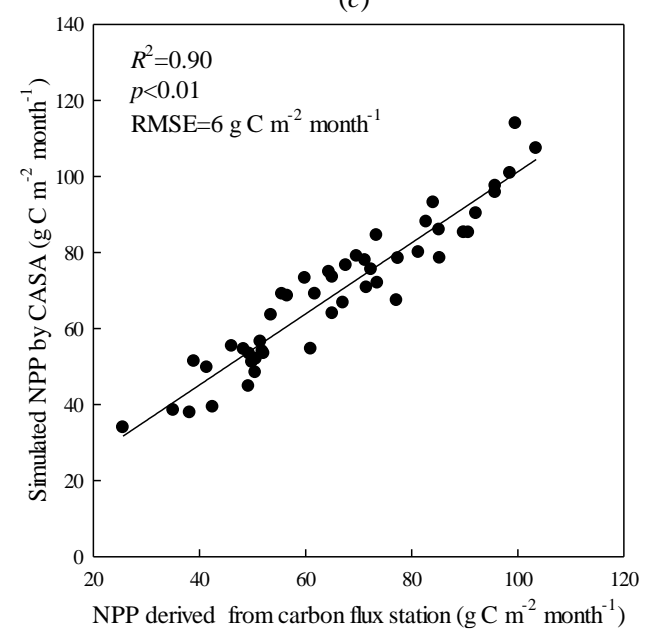

(b)

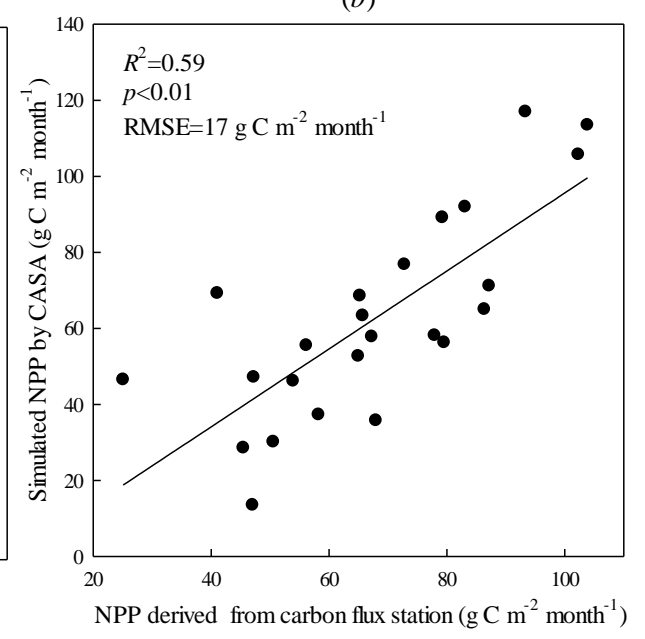

Figure 4. Comparison of $(a)$ the simulated annual NPP with the observed NPP at the eight sampling plots in Tianmu Mountain Nature Reserve, and comparison of the simulated monthly

NPP with the NPP derived from the carbon flux stations (b) from 2013 to 2014 in TianMu Mountain Nature Reserve and (c) from 2011 to 2014 in Anji

The $\mathrm{NPP}_{\text {act }}$ derived from the eddy covariance observation systems in TianMu Mountain Nature Reserve (see Fig. 4b) and Anji (see Fig. 4c) were also used to validate the simulated NPPact. The results show that the monthly NPP act simulated by CASA model was largely consistent with the $\mathrm{NPP}_{\text {act }}$ derived from the eddy covariance 
observation systems $\left(R^{2} \geq 0.59, p<0.01\right)$. Therefore, the $\mathrm{NPP}_{\text {act }}$ simulated by CASA model can be used for HANPPluc estimation.

\section{NPP pot estimation and validation}

The $\mathrm{NPP}_{\mathrm{pot}}$ in the croplands in Anji from 1984 to 2014 was simulated by the Thornthwaite Memorial model (see Eqs. 3-5). According to Tobler's first law (TFL) of geography, the NPP pot in the SBF, SNLF, and MBF in Anji would be considered to be equal to that in the core zone in TianMu Mountain Nature Reserve. Based on the monthly CASA-simulated $\mathrm{NPP}_{\text {act }}$, temperature $\left(T_{a}\right)$, precipitation $(P)$, and solar radiation $(S)$ for eight months (January, February, April, May, July, August, October, and November) from 1984 to 2014 in the core zone in TianMu Mountain Nature

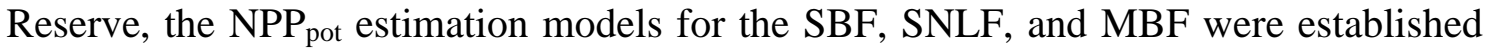
using multiple linear regression (see Table 3).

Table 3. The NPP $P_{\text {pot }}$ estimation models for each forest type

\begin{tabular}{c|c|c|c}
\hline Forest type & NPP pot estimation models & $\mathbf{R}^{\mathbf{2}}$ & $\boldsymbol{p}$ \\
\hline $\mathrm{SBF}$ & $\mathrm{NPP}_{\mathrm{pot}}=2.26 \times T_{a}-0.02 \times P+0.29 \times \mathrm{S}-69.90$ & 0.74 & $<0.01$ \\
$\mathrm{SNLF}$ & $\mathrm{NPP}_{\mathrm{pot}}=1.96 \times T_{a}-0.02 \times P+0.27 \times S-62.38$ & 0.71 & $<0.01$ \\
$\mathrm{MBF}$ & $\mathrm{NPP}_{\mathrm{pot}}=2.54 \times T_{a}-0.01 \times P+0.28 \times S-70.60$ & 0.76 & $<0.01$ \\
\hline
\end{tabular}

$T_{a}$ : temperature, $P$ : precipitation, $S:$ solar radiation

The monthly mean CASA-simulated NPPact for four months (March, June, September and December) from 1984 to 2014 in the core zone in TianMu Mountain Nature Reserve was used to validate the simulated monthly mean NPP pot of the three forest types (see Fig. 5). The results show that the simulated $\mathrm{NPP}_{\text {pot }}$ was consistent with the CASA-simulated NPP act $\left(R^{2} \geq 0.68, p<0.01\right)$.

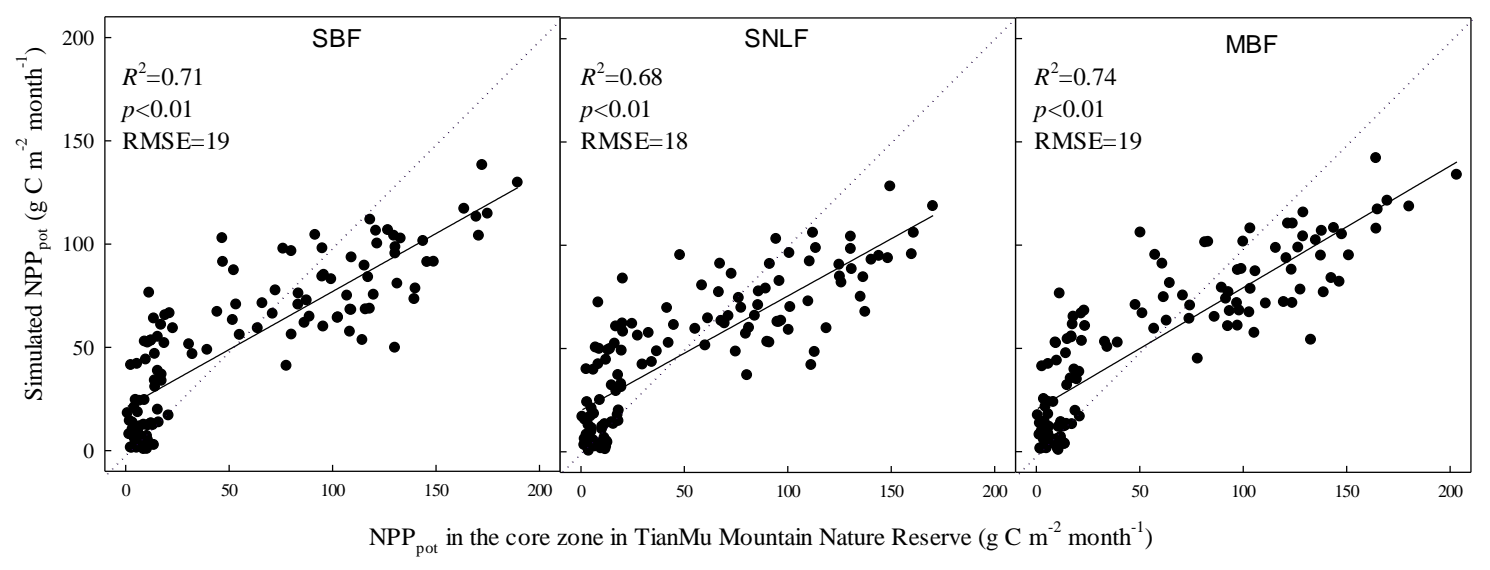

Figure 5. Comparison of the simulated NPP pot with the NPP pot in the core zone in TianMu Mountain Nature Reserve

\section{HANPP $_{\text {luc }}$ interannual variability}

The HANPP $_{\text {luc }}$ in Anji from 1984 to 2014 were calculated using Equation 1. Using Equation 9, we can find that there was a significant increasing trend with the rate of 
$2 \mathrm{~g} \mathrm{C} \mathrm{m}^{-2}$ year $^{-1}$ in annual HANPPluc, increasing from $1 \mathrm{~g} \mathrm{C} \mathrm{m}^{-2}$ year $^{-1}$ in 1984 to $48 \mathrm{~g} \mathrm{C} \mathrm{m}^{-2}$ year $^{-1}$ in 2014 (see Fig. 6). The highest annual HANPPluc appeared in 2007, with the value of $248 \mathrm{~g} \mathrm{C} \mathrm{m}^{-2}$ year $^{-1}$, while the lowest annual HANPP luc appeared in 1984, with the value of $1 \mathrm{~g} \mathrm{C} \mathrm{m}^{-2}$ year $^{-1}$. The annual averaged HANPP luc was $82 \mathrm{~g} \mathrm{C} \mathrm{m}^{-2}$ year ${ }^{-1}$, and it means that the NPP act decreased about $82 \mathrm{~g} \mathrm{C} \mathrm{m}^{-2}$ year-1 due to the LUC.

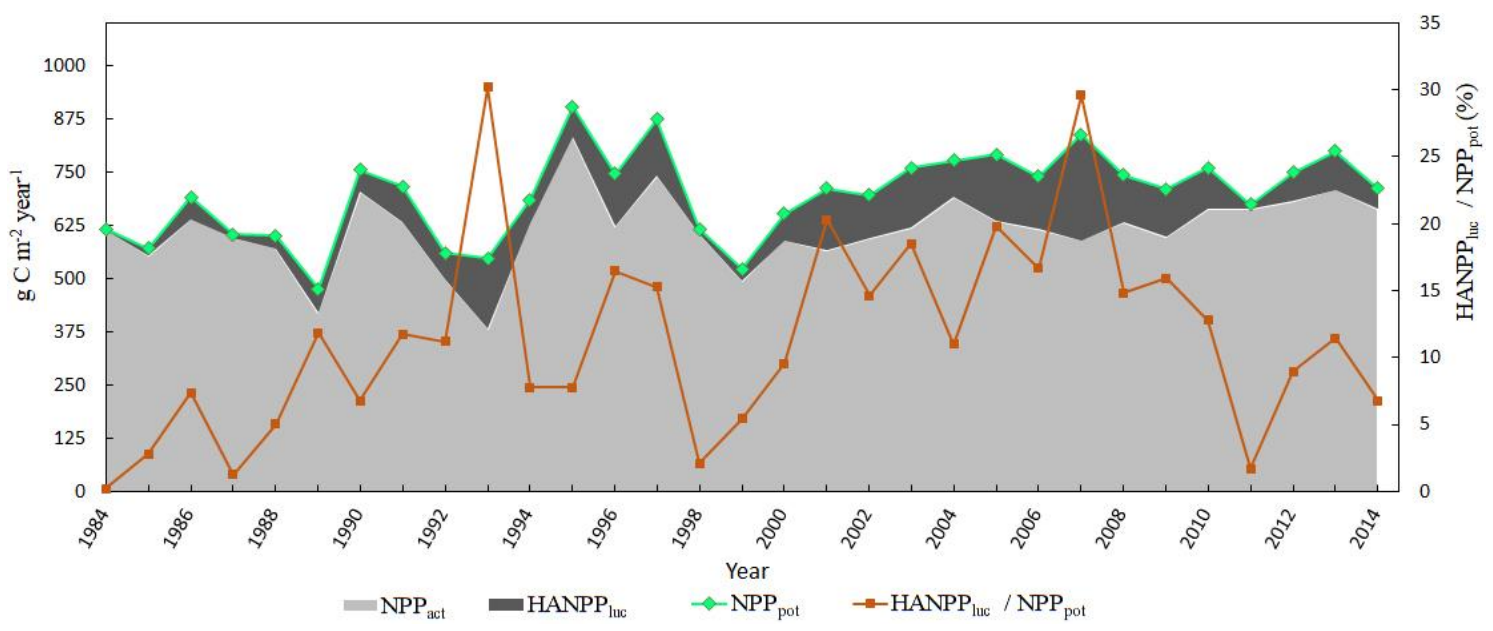

Figure 6. Interannual changes in the annual NPP $P_{a c t}, H A N P P_{l u c}, N P P_{p o t}$, and $H A N P P_{l u d} / N P P_{p o t}$ in Anji during the period 1984-2014

The increase of HANPP luc $_{\text {is }}$ also visible in the increase of HANPP luc $_{\text {a }}$ as a percentage of $\mathrm{NPP}_{\text {pot }}$ (i.e. HANPP $\mathrm{Huc}_{\mathrm{NPP}} \mathrm{NPt}_{\mathrm{pot}}$, which increased from $0.2 \%$ in 1984 to $6.7 \%$ in 2014. The highest annual HANPPluc $\mathrm{NPP}_{\text {pot }}$ also appeared in 2007 , with the value of $29.6 \%$, while the lowest annual HANPP $\mathrm{Hud}_{\mathrm{NPP}}$ pot appeared in 1984, with the value of $0.2 \%$. The annual averaged $\mathrm{HANPP}_{\text {lud }} / \mathrm{NPP}_{\text {pot }}$ was $11 \%$, which means that the $\mathrm{NPP}_{\text {act }}$

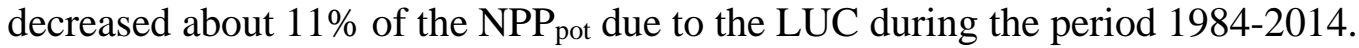

Figure 6 also shows that there was a significant upward trends in the annual $\mathrm{NPP}_{\text {act }}$ in Anji, and the rate of increase was $3.0 \mathrm{~g} \mathrm{C} \mathrm{m}^{-2}$ year ${ }^{-1}$. The annual $\mathrm{NPP}_{\text {act }}$ varied between 382 and $833 \mathrm{~g} \mathrm{C} \mathrm{m}^{-2}$ year $^{-1}$, and annual averaged $\mathrm{NPP}_{\text {act }}$ was $614 \mathrm{~g} \mathrm{C} \mathrm{m}^{-2}$ year1. There was also a significant upward trends in the annual $\mathrm{NPP}_{\text {pot }}$ in Anji, and the rate of increase was $5.4 \mathrm{~g} \mathrm{C} \mathrm{m}^{-2}$ year $^{-1}$. The annual $\mathrm{NPP}_{\text {pot }}$ varied between 474 and $903 \mathrm{~g} \mathrm{C} \mathrm{m}^{-2}$ year ${ }^{-1}$, and annual averaged $\mathrm{NPP}_{\text {pot }}$ was $697 \mathrm{~g} \mathrm{C} \mathrm{m}^{-2}$ year $^{-1}$.

\section{Spatial pattern of HANPPluc}

In Anji, the total mean value of $\mathrm{HANPP}_{\text {luc }}$ was $155 \mathrm{Gg} \mathrm{C}$ year $^{-1}$, while $\mathrm{HANPP}_{\text {luc }}$ per unit was $82 \pm 54 \mathrm{~g} \mathrm{C} \mathrm{m}^{-2}$ year ${ }^{-1}$ from 1984 to 2014. The HANPPluc in central Anji were higher than those in other regions (see Fig. 7a). In general, the positive HANPPluc, i.e. $\mathrm{NPP}_{\text {pot }}$ was higher than $\mathrm{NPP}_{\text {act}}$, appeared in northern, southern and central Anji, while the negative $\mathrm{HANPP}_{\text {luc }}$ appeared in eastern and western Anji. The area of the negative $\mathrm{HANPP}_{\text {luc }}$ regions was 73723 ha, accounting for $39 \%$ of Anji area. The MBF is widely distributed in those regions, $\mathrm{NPP}_{\text {act }}$ was higher than $\mathrm{NPP}_{\text {pot }}$ because of $\mathrm{MBF}$ management like the On and Off-year management and fertilization (Chen et al., 2018; Zhang et al., 2017a).

Although there was an increasing trend in the annual HANPPluc, the changing trends

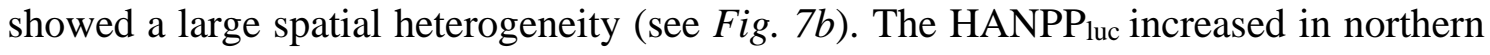


and central Anji because of the urbanization and decrease of croplands. The area where the HANPPluc increased significantly was 11342 ha, accounting for 6\% of Anji area (see

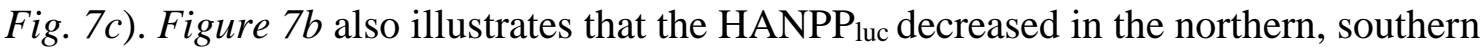
and central Anji due to land cover changes to highly productive land type (MBF). The area where the $\mathrm{HANPP}_{\text {luc }}$ decreased significantly was 13232 ha, accounting for $7 \%$ of Anji area (see Fig. 7c).

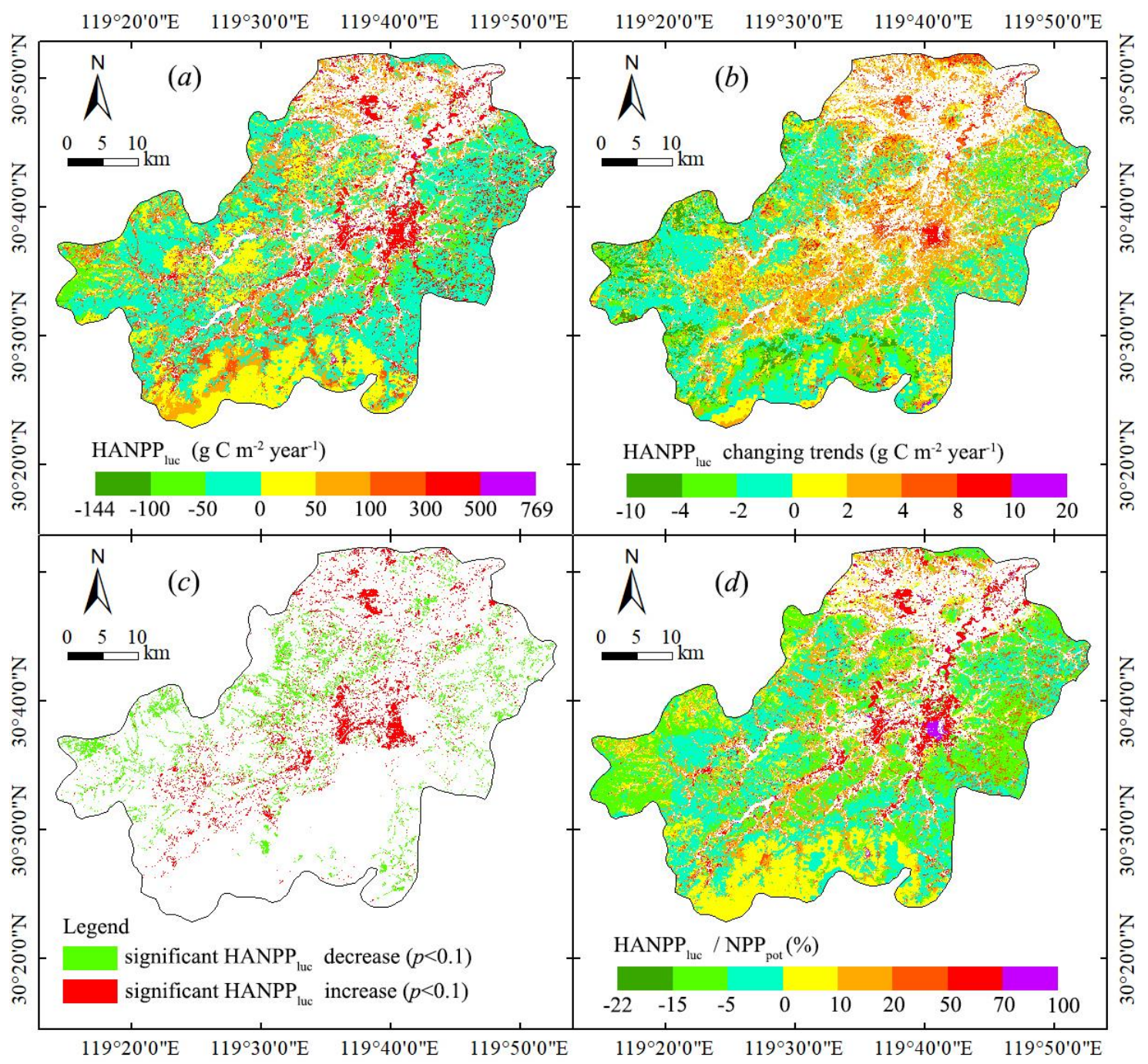

Figure 7. Spatial distributions of (a) annual HANPP ${ }_{l u c},(b)$ changing trends in HANPP $P_{l u c},(c)$ significant HANPP luc change $(p<0.1)$, and $(d)$ annual averaged HANPP lud $/ N P P_{\text {pot }}$ from 1984 to 2014 in Anji

Over the 31 years, the mean value of the ratio between $\mathrm{HANPP}_{\text {luc }}$ and $\mathrm{NPP}_{\text {pot }}$ (i.e. $\mathrm{HANPP}_{\text {luc }}\left(\mathrm{NPP}_{\text {pot }}\right)$ was $11 \pm 7 \%$. The positive $\mathrm{HANPP}$ luc $\mathrm{NPP}_{\text {pot }}$ values were distributed in the northern, southern and central Anji (see Fig. 7d), and the highest value of $\mathrm{HANPP}_{\text {luc }} / \mathrm{NPP}_{\text {pot }}$ appeared in central Anji due to land cover changes to urban land. The negative $\mathrm{HANPP}$ luc $\mathrm{NPP}_{\text {pot }}$ values appeared in eastern and western Anji, and the lowest value of HANPP luc $\mathrm{NPP}_{\text {pot }}$ was in eastern Anji because of land cover changes to highly productive land type $(\mathrm{MBF})$. 


\section{Discussion}

\section{Comparison with previous work}

Compared with previous work (see Table 4), the simulated $\mathrm{NPP}_{\text {pot }}$ in Anji was similar to the result in the core zone in Tianmu Mountain Nature Reserve (Chen et al., 2017), karst areas of south China (Lin et al., 2016), and coastal areas of Jiangsu (Zhang et al., 2015). However, the simulated $\mathrm{NPP}_{\text {pot }}$ was lower than the result in Zhejiang reported by Pan (2020), and was higher than the result in Yangtze River Delta reported by Huang (2020).

For SBF, the simulated $\mathrm{NPP}_{\text {pot }}$ in Anji was similar to the result in the core zone in Tianmu Mountain Nature Reserve (Chen et al., 2017), Zhejiang (Sun, 2009), Gannan (Zou et al., 2011), and China (Lin et al., 2012). For SNLF, the simulated NPP $_{\text {pot }}$ in Anji was similar to the result in the core zone in Tianmu Mountain Nature Reserve (Chen et al., 2017), Zhejiang (Sun, 2009), and global tropical and subtropical needle leaf forests (Medková et al., 2017). Our result was higher than the result in cold temperate needle leaf forests in China reported by Ren (2017). For MBF, the simulated $\mathrm{NPP}_{\text {pot }}$ in Anji was similar to the result in the core zone in Tianmu Mountain Nature Reserve (Chen et al., 2017). However, it was lower than the result in Wuyishan Biosphere Reserve (Li et al., 2006). For croplands, the simulated $\mathrm{NPP}_{\text {pot }}$ in Anji was higher than the result in global croplands (Haberl et al., 2007).

Table 4. Overview of previous work on $N P P_{\text {pot }}$ at different scale

\begin{tabular}{|c|c|c|c|}
\hline Work & Study scale & Time period & $\begin{array}{c}\mathbf{N P P}_{\text {pot }} \\
\left(\mathrm{g} \mathrm{C} \mathrm{m}^{-2} \text { year }^{-1}\right)\end{array}$ \\
\hline This study & Anji, China & $1984-2014$ & $697 \pm 100$ \\
\hline Chen et al., 2017 & The core zone in Tianmu Mountain Nature Reserve & 1984-2014 & $720 \pm 114$ \\
\hline Lin et al., 2016 & Karst areas of south China & $2000-2013$ & $400-850$ \\
\hline Zhang et al., 2015 & Coastal areas of Jiangsu, China & $2000-2010$ & $603-832$ \\
\hline Pan and $\mathrm{Xu}, 2020$ & Zhejiang, China & $1981-2015$ & 896 \\
\hline Huang et al., 2020 & Yangtze River Delta, China & 2005-2015 & $424-631$ \\
\hline This study & SBF in Anji & $1984-2014$ & $775 \pm 106$ \\
\hline Chen et al., 2017 & SBF in the core zone in Tianmu Mountain Nature Reserve & $1984-2014$ & $717 \pm 120$ \\
\hline Sun, 2009 & SBF in Zhejiang & 1981-1998 & $500-800$ \\
\hline Zou et al., 2011 & SBF in Gannan & $1950-2000$ & 733 \\
\hline Lin et al., 2012 & SBF in China & $1961-2006$ & $534-847$ \\
\hline This study & SNLF in Anji & $1984-2014$ & $720 \pm 97$ \\
\hline Chen et al., 2017 & SNLF in the core zone in Tianmu Mountain Nature Reserve & $1984-2014$ & $665 \pm 94$ \\
\hline Medková et al., 2017 & Global tropical and subtropical NLF & 2000 & 735 \\
\hline Sun, 2009 & SNLF in Zhejiang & $1981-1998$ & $500-800$ \\
\hline Ren et al., 2017 & Cold temperate NLF in China & $1982-2012$ & 430 \\
\hline This study & MBF in Anji, China & $1984-2014$ & $805 \pm 108$ \\
\hline Chen et al., 2017 & MBF in the core zone in Tianmu Mountain Nature Reserve & $1984-2014$ & $731-784$ \\
\hline Li et al., 2006 & MBF in Wuyishan Biosphere Reserve & 1993 & 826 \\
\hline This study & Croplands in Anji, China & $1984-2014$ & $670 \pm 63$ \\
\hline Haberl et al., 2007 & Global croplands & 2000 & 611 \\
\hline
\end{tabular}

NLF: needle leaf forests 
During the period 1984-2014, the annual HANPPluc varied between 1 and $248 \mathrm{~g} \mathrm{C} \mathrm{m}^{-2}$ year ${ }^{-1}$, with the mean value of $82 \pm 54 \mathrm{~g} \mathrm{C} \mathrm{m}^{-2}$ year $^{-1}$ (see Table 5). Our results were similar to the results in the regions where the geographic and climatic conditions are similar to Anji (Huang et al., 2020; Zhang et al., 2015). The national HANPP ${ }_{\text {luc }}$ values from previous studies were also compared with the annual $\mathrm{HANPP}_{\text {luc }}$ in Anji, and the results show that our results were similar to the results in China (Chen et al., 2015) and New Zealand (Fetzel et al., 2014). However, the result was higher than the global result reported by Haberl (2007).

In Anji, the ratio between $\mathrm{HANPP}_{\text {luc }}$ and $\mathrm{NPP}_{\text {pot }}$ (i.e. $\mathrm{HANPP}_{\text {luc }} / \mathrm{NPP}_{\text {pot }}$ ) varied between $0.2 \%$ and $29.6 \%$, with the mean value of $11 \pm 7 \%$. Our results were similar to the results in the regions where the geographic and climatic conditions are similar to Anji (Huang et al., 2020; Zhang et al., 2015). The result was also similar to the result in Karst areas of south China (Lin et al., 2016). As shown in Table 5, distinct differences in $\mathrm{HANPP}$ luc $/ \mathrm{NPP}_{\text {pot }}$ are found in different countries and regions. The HANPP $\mathrm{Huc}_{\mathrm{NPP}} \mathrm{NP}_{\mathrm{pot}}$ in China was higher than that in East Asia or Europe (Chen et al., 2015; Haberl et al., 2007; Plutzar et al., 2016), and was similar to the result in Central Asia (Huang et al., 2018). The variation of the HANPPluc $\mathrm{NPP}_{\text {pot }}$ in New Zealand or global terrestrial ecosystems was larger than that in China (Fetzel et al., 2014; Haberl et al., 2014). The $\mathrm{HANPP}_{\text {luc }} / \mathrm{NPP}_{\text {pot }}$ in Anji was lower than that in China, this is mainly caused by the increase of the area of forest types, increasing from 59\% in 1984 to $66 \%$ in 2014 (see Table 2).

Table 5. Overview of previous work on HANPP $P_{\text {luc }}$ at different scale

\begin{tabular}{c|c|c|c|c}
\hline Quantity & Study scale & Time period & Results & References \\
\hline \multirow{5}{*}{ HANPP $_{\text {luc }}$} & Anji, China & $1984-2014$ & $82 \pm 54$ & This study \\
& Zhejiang, China & $2005-2015$ & 71 & Huang et al., 2020 \\
& Coastal areas of Jiangsu, China & $2000-2010$ & $-23-100$ & Zhang et al., 2015 \\
& Yangtze River Delta, China & $2005-2015$ & $26-102$ & Huang et al., 2020 \\
& China & $2001-2010$ & $45-121$ & Chen et al., 2015 \\
& New Zealand & $1860-2005$ & $11-96$ & Fetzel et al., 2014 \\
& Global & 2000 & 4 & Haberl et al., 2007 \\
\hline \multirow{5}{*}{ HANPP $\left.^{-1}\right)$} & Anji, China & $1984-2014$ & $11 \pm 7 \%$ & This study \\
& Coastal areas of Jiangsu, China & $2000-2010$ & $-11 \%-32 \%$ & Zhang et al., 2015 \\
& Yangtze River Delta, China & $2005-2015$ & $6 \%-19 \%$ & Huang et al., 2020 \\
& Karst areas of south China & $2000-2013$ & $13 \%-22 \%$ & Lin et al., 2016 \\
& China & $2001-2010$ & $11 \%-26 \%$ & Chen et al., 2015 \\
& East Asia & 2000 & $5 \%$ & Haberl et al., 2007 \\
& Central Asia & $1979-2012$ & $0.3 \%-22 \%$ & Huang et al., 2018 \\
& Europe & $1990-2006$ & $11 \%$ & Plutzar et al., 2016 \\
& New Zealand & $1860-2005$ & $4 \%-37 \%$ & Fetzel et al., 2014 \\
& Global & 2000 & $4 \%-55 \%$ & Haberl et al., 2014 \\
\hline
\end{tabular}

\section{Impact of land use changes on NPP}

Based on the HANPPluc and transition of different land cover types during the period

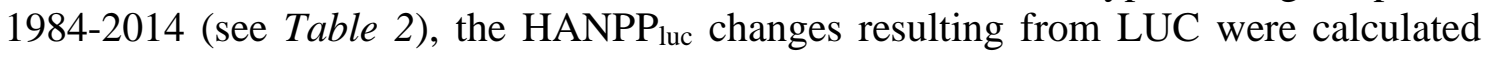


(see Table 6). MBF has a strong capacity for carbon sequestration (Cao et al., 2019; Chen et al., 2020). Therefore, because of the increase of the MBF, which increased about 25207 ha during the period 1984-2014, the HANPP luc $_{\text {in }}$ the MBF decreased from $49.0 \mathrm{Gg} \mathrm{C}$ year $^{-1}$ in 1984 to $15.5 \mathrm{Gg} \mathrm{C}$ year $^{-1}$ in 2014 . It means that the NPP increased about $33.5 \mathrm{Gg} \mathrm{C}$ year $^{-1}$ due to the increase of MBF.

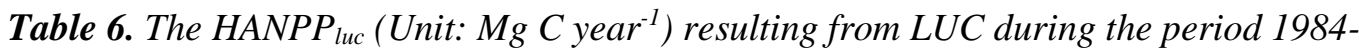
2014 in Anji

\begin{tabular}{c|c|c|c|c|c|c|c}
\hline Type & SBF & SNLF & MBF & Croplands & Urban & River & Total \\
\hline SBF & 19,192 & 138 & 1,481 & -390 & 3,612 & 637 & 24,670 \\
SNLF & 503 & $-2,523$ & $-4,211$ & $-2,782$ & 5,757 & 111 & $-3,145$ \\
MBF & 3,449 & 1,770 & 15,600 & 701 & 27,369 & 129 & 49,018 \\
Croplands & 3,484 & 1,059 & 4,358 & 2,953 & 49,732 & 4,267 & 65,853 \\
Urban & -91 & -215 & $-1,631$ & $-9,480$ & 0 & 0 & $-11,417$ \\
River & -45 & 0 & -93 & 45 & 0 & 0 & -93 \\
Total & 26,493 & 228 & 15,504 & $-8,952$ & 86,469 & 5,144 & \\
\hline
\end{tabular}

The area of the SBF decreased about 7316 ha during the period 1984-2014, while the HANPP $_{\text {luc }}$ in the SBF increased from $24.7 \mathrm{Gg} \mathrm{C}_{\text {year }}{ }^{-1}$ in 1984 to $26.5 \mathrm{Gg} \mathrm{C}_{\text {year }}{ }^{-1}$ in 2014. It means that the NPP decreased about $1.8 \mathrm{Gg} \mathrm{C}$ year $^{-1}$. The area of the SNLF decreased about 5666 ha, which caused the NPP decrease of $3.4 \mathrm{Gg} \mathrm{C}_{\text {year }}{ }^{-1}$. The area of the urban land increased about 12291 ha, which caused the NPP decrease of $97.9 \mathrm{Gg}$ $\mathrm{C}$ year $^{-1}$. The area of the river increased about 809 ha, and it led to a decrease of $5.2 \mathrm{Gg}$ C year ${ }^{-1}$ in the NPP.

The area of the croplands decreased about 25323 ha during the period 1984-2014, and the area of the croplands occupied by MBF, SBF, or SNLF was about 16739 ha. In the vast majority of the global terrestrial ecosystems, converting croplands to forests increases NPP (Krausmann et al., 2013). As a consequence, the NPP increased $7.5 \mathrm{Gg} \mathrm{C}_{\mathrm{Cear}}{ }^{-1}$.

\section{Conclusion}

Based on the CASA model and the Thornthwaite Memorial model, this paper calculated the $\mathrm{NPP}_{\text {act }}$ and $\mathrm{NPP}_{\text {pot }}$ in Anji during the period 1984-2014, explored the temporal and spatial changes of HANPPluc in Anji, and analyzed the impact of LUC on vegetation NPP. The main findings are as follows:

(1) Over the 31 years, there was an increasing trend in the annual HANPPluc, but the changing trends showed a large spatial heterogeneity. The HANPP luc $_{\text {increased in }}$ northern and central Anji because of the urbanization and decrease of the croplands.

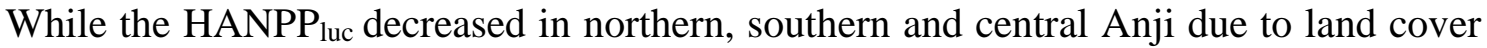
changes to highly productive land type (MBF).

(2) In general, the $\mathrm{HANPP}_{\text {luc }}$ in central Anji were higher than those in other regions. The positive $\mathrm{HANPP}_{\text {luc }}$, i.e. NPP $\mathrm{NP}_{\text {pot }}$ was higher than $\mathrm{NPP}_{\text {act }}$, appeared in northern, southern and central Anji, while the negative HANPP luc appeared in eastern and western Anji.

(3) The increase of the MBF led to an increase in NPP, while converting croplands to forests also increased NPP. However, the increase of the urban land and river caused the 
NPP decreasing significantly. Our results indicate that MBF is a good substitute for wood due to its strong capacity for carbon sequestration, and we also should control of the expansion of urban land.

The long-term forecasting and evaluation of the temporal and spatial changes of HANPP $_{\text {luc }}$ has more important significance for land use management, and it is our future studies.

Acknowledgements. This work was supported by the Jiangsu Provincial Department of Education Foundation of China [Grant number 2020SJA0541]; the Major Project of the Philosophy and Social Science Foundation of the Jiangsu Higher Education Institutions of China [Grant number 2021SJZDA130]; and the Ministry of Education Foundation of China [Grant number 19JZD023]; and Scientific Research Foundation for Talented Scholars of Jinling Institute of Technology (under grant JITB-202031).

\section{REFERENCES}

[1] Cao, L., Coops, N. C., Sun, Y., Ruan, H., Wang, G., Dai, J., She, G. (2019): Estimating canopy structure and biomass in bamboo forests using airborne LiDAR data. - ISPRS Journal of Photogrammetry and Remote Sensing 148: 114-129.

[2] Chen, A., Li, R., Wang, H., He, B. (2015): Quantitative assessment of human appropriation of aboveground net primary production in China. - Ecological Modelling 312: 54-60.

[3] Chen, S., Jiang, H., Jin, J., Wang, Y. (2017): Changes in net primary production in the Tianmu Mountain Nature Reserve, China, from 1984 to 2014. - International Journal of Remote Sensing 38: 211-234.

[4] Chen, S., Jiang, H., Cai, Z., Zhou, X., Peng, C. (2018): The response of the net primary production of Moso bamboo forest to the On and Off-year management: a case study in Anji County, Zhejiang, China. - Forest Ecology and Management 409: 1-7.

[5] Chen, S., Jiang, H., Chen, Y., Cai, Z. (2020): Spatial-temporal patterns of net primary production in Anji (China) between 1984 and 2014. - Ecological Indicators 110.

[6] Fetzel, T., Gradwohl, M., Erb, K.-H. (2014): Conversion, intensification, and abandonment: a human appropriation of net primary production approach to analyze historic land-use dynamics in New Zealand 1860-2005. - Ecological Economics 97: 201208.

[7] Field, C. B., Randerson, J. T., Malmström, C. M. (1995): Global net primary production: combining ecology and remote sensing. - Remote Sensing of Environment 51: 74-88.

[8] Foley, J. A., Defries, R., Asner, G. P., Barford, C., Bonan, G., Carpenter, S. R., Chapin, F. S., Coe, M. T., Daily, G. C., Gibbs, H. K., Helkowski, J. H., Holloway, T., Howard, E. A., Kucharik, C. J., Monfreda, C., Patz, J. A., Prentice, I. C., Ramankutty, N., Snyder, P. K. (2005): Global consequences of land use. - Science 309: 570-574.

[9] Gang, C., Zhou, W., Chen, Y., Wang, Z., Sun, Z., Li, J., Qi, J., Odeh, I. (2014): Quantitative assessment of the contributions of climate change and human activities on global grassland degradation. - Environmental Earth Sciences 72: 4273-4282.

[10] Garbulsky, M. F., Paruelo, J. M. (2004): Remote sensing of protected areas to derive baseline vegetation functioning characteristics. - Journal of Vegetation Science 15: 711720.

[11] Geneletti, D., Duren, I. V. (2008): Protected area zoning for conservation and use: a combination of spatial multicriteria and multiobjective evaluation. - Landscape and Urban Planning 85: 97-110.

[12] Haberl, H., Erb, K. H., Krausmann, F., Gaube, V., Bondeau, A., Plutzar, C., Gingrich, S., Lucht, W., Fischer-Kowalski, M. (2007): Quantifying and mapping the human 
appropriation of net primary production in earth's terrestrial ecosystems. - Proc Natl Acad Sci USA 104: 12942-12947.

[13] Haberl, H., Erb, K.-H., Krausmann, F. (2014): Human appropriation of net primary production: patterns, trends, and planetary boundaries. - Annual Review of Environment and Resources 39: 363-391.

[14] Huang, X., Luo, G., Han, Q. (2018): Temporospatial patterns of human appropriation of net primary production in Central Asia grasslands. - Ecological Indicators 91: 555-561.

[15] Huang, Q., Zhang, F., Zhang, Q., Ou, H., Jin, Y. (2020): Quantitative assessment of the impact of human activities on terrestrial net primary productivity in the Yangtze River delta. - Sustainability 12.

[16] Hull, V., Xu, W., Liu, W., Zhou, S., Viña, A., Zhang, J., Tuanmu, M.-N., Huang, J., Linderman, M., Chen, X., Huang, Y., Ouyang, Z., Zhang, H., Liu, J. (2011): Evaluating the efficacy of zoning designations for protected area management. - Biological Conservation 144: 3028-3037.

[17] IPCC (2013): Climate Change 2013: The Physical Science Basis. Contribution of Working Group I to the Fifth Assessment Report of the Intergovernmental Panel on Climate Change. - Cambridge University Press, Cambridge UK, New York.

[18] Krausmann, F., Erb, K.-H., Gingrich, S., Haberl, H., Bondeau, A., Gaube, V., Lauk, C., Plutzar, C., Searchinger, T. D. (2013): Global human appropriation of net primary production doubled in the 20th century. - Proc Natl Acad Sci USA 110: 10324-10329.

[19] Li, Z. J., Lin, P., He, J. Y., Yang, Z. W., Lin, Y. M. (2006): Silicon's organic pool and biological cycle in moso bamboo community of Wuyishan Biosphere Reserve. - J Zhejiang Univ Sci B 7: 849-857.

[20] Lieth, H. (1975): Modeling the Primary Productivity of the World. - In: Lieth, H., Whittaker, R. H. (eds.) Primary Productivity of the Biosphere. Springer, New York, pp. 237-264.

[21] Lin, D., Yu, H., Lian, F., Wang, J.-a., Zhu, A. X., Yue, Y. (2016): Quantifying the hazardous impacts of human-induced land degradation on terrestrial ecosystems: a case study of karst areas of south China. - Environmental Earth Sciences 75.

[22] Lin, H., Zhao, J. U. N., Liang, T., Bogaert, J. A. N., Li, Z. (2012): A classification indices-based model for net primary productivity (Npp) and potential productivity of vegetation in China. - International Journal of Biomathematics 05: 1-23.

[23] Liu, Y., Zhang, Z., Tong, L., Khalifa, M., Wang, Q., Gang, C., Wang, Z., Li, J., Sun, Z. (2019): Assessing the effects of climate variation and human activities on grassland degradation and restoration across the globe. - Ecological Indicators 106.

[24] Lü, D., Gao, G., Lü, Y., Xiao, F., Fu, B. (2020): Detailed land use transition quantification matters for smart land management in drylands: an in-depth analysis in Northwest China. - Land Use Policy 90.

[25] Mahbub, R. B., Ahmed, N., Rahman, S., Hossain, M. M., Sujauddin, M. (2019): Human appropriation of net primary production in Bangladesh, 1700-2100. - Land Use Policy 87.

[26] Medková, H., Vačkár̆, D., Weinzettel, J. (2017): Appropriation of potential net primary production by cropland in terrestrial ecoregions. - Journal of Cleaner Production 150: 294-300.

[27] Pan, J., Xu, B. (2020): Modeling spatial distribution of potential vegetation NPP in China. - Chinese Journal of Ecology 39: 1001-1012.

[28] Plutzar, C., Kroisleitner, C., Haberl, H., Fetzel, T., Bulgheroni, C., Beringer, T., Hostert, P., Kastner, T., Kuemmerle, T., Lauk, C., Levers, C., Lindner, M., Moser, D., Müller, D., Niedertscheider, M., Paracchini, M. L., Schaphoff, S., Verburg, P. H., Verkerk, P. J., Erb, K.-H. (2016): Changes in the spatial patterns of human appropriation of net primary production (HANPP) in Europe 1990-2006. - Regional Environmental Change 16: 12251238 . 
[29] Potter, C. S., Randerson, J. T., Field, C. B., Matson, P. A., Vitousek, P. M., Mooney, H. A., Klooster, S. A. (1993): Terrestrial ecosystem production: a process model based on global satellite and surface data. - Global Biogeochemical Cycles 7: 811-841.

[30] Pritchard, R., Ryan, C. M., Grundy, I., van der Horst, D. (2018): Human appropriation of net primary productivity and rural livelihoods: findings from six villages in Zimbabwe. Ecological Economics 146: 115-124.

[31] Ren, z., Zhu, H., Shi, H., Liu, X. (2017): Spatiotemporal-distribution pattern variation of net primary productivity in potential natural vegetation and its response to climate and topography in China. - Acta Agrestia Sinica 25: 474-485.

[32] Saikku, L., Mattila, T., Akujärvi, A., Liski, J. (2015): Human appropriation of net primary production in Finland during 1990-2010. - Biomass and Bioenergy 83: 559-567.

[33] Shi, T., Yang, S., Zhang, W., Zhou, Q. (2020): Coupling coordination degree measurement and spatiotemporal heterogeneity between economic development and ecological environment-empirical evidence from tropical and subtropical regions of China. - Journal of Cleaner Production 244.

[34] Song, X., Peng, C., Zhou, G., Jiang, H., Wang, W., Xiang, W. (2013): Climate warminginduced upward shift of Moso bamboo population on Tianmu Mountain, China. - Journal of Mountain Science 10: 363-369.

[35] Song, X., Peng, C., Zhou, G., Gu, H., Li, Q., Zhang, C. (2016): Dynamic allocation and transfer of non-structural carbohydrates, a possible mechanism for the explosive growth of Moso bamboo (Phyllostachys heterocycla). - Scientific Reports 6.

[36] Sun, G. (2009): Simulation of potential vegetation distribution and estimation of carbon flux in China from 1981 to 1998 with LPJ dynamic global vegetation model. - Climatic and Environmental Research 14: 341-351.

[37] Waters, N. (2017): Tobler's First Law of Geography. - In: International Encyclopedia of Geography: People, the Earth, Environment and Technology. Wiley-Interscience, New York.

[38] Weinzettel, J., Vačkářů, D., Medková, H. (2019): Potential net primary production footprint of agriculture: a global trade analysis. - Journal of Industrial Ecology 23: 11331142.

[39] Xu, H.-j., Wang, X.-p. (2016): Effects of altered precipitation regimes on plant productivity in the arid region of northern China. - Ecological Informatics 31: 137-146.

[40] Yin, L., Dai, E., Zheng, D., Wang, Y., Ma, L., Tong, M. (2020): What drives the vegetation dynamics in the Hengduan Mountain region, southwest China: climate change or human activity? - Ecological Indicators 112.

[41] Zhang, F., Pu, L., Huang, Q. (2015): Quantitative assessment of the human appropriation of net primary production (HANPP) in the coastal areas of Jiangsu, China. Sustainability 7: 15857-15870.

[42] Zhang, T., Peng, J., Liang, W., Yang, Y., Liu, Y. (2016): Spatial-temporal patterns of water use efficiency and climate controls in China's Loess Plateau during 2000-2010. The Science of the Total Environment 565: 105-122.

[43] Zhang, J., Lv, J., Li, Q., Ying, Y., Peng, C., Song, X. (2017a): Effects of nitrogen deposition and management practices on leaf litterfall and $\mathrm{N}$ and $\mathrm{P}$ return in a Moso bamboo forest. - Biogeochemistry 134: 115-124.

[44] Zhang, L., Luo, Z., Mallon, D., Li, C., Jiang, Z. (2017b): Biodiversity conservation status in China's growing protected areas. - Biological Conservation 210: 89-100.

[45] Zhu, W., Pan, Y., He, H., Yu, D., Hu, H. (2006): Simulation of maximum light use efficiency for some typical vegetation types in China. - Chinese Science Bulletin 51: 457-463.

[46] Zou, D., Feng, Q., Liang, T. (2011): Research on Grassland Classification and NPP in Gannan Region. - Remote Sensing Technology and Application 26: 577-583. 